DOI: https://doi.org/10.51209/platform.2.4.2021.45-59

UDC: $7.78: 784 ; 8.81$

Nataliia V. ZEMLIANSKA,

$\mathrm{PhD}$ in Public Administration,

Kyiv Municipal Academy of Circus

and Performing Arts,

Kyiv, Ukraine,

e-mail: n.zemlyanska@kmaecm.edu.ua,

ORCID: 0000-0002-2192-8380

\title{
USING POP SONGS IN TEACHING ENGLISH LANGUAGE TO STUDENTS MAJORING IN MUSIC ARTS. PHONOLOGICAL ASPECT
}

\begin{abstract}
In the process of foreign language acquisition, students can face various obstacles, which can prevent them from achieving the desired goal. English pronunciation is traditionally considered one of the most challenging issues, which require special approach and teaching techniques to tackle. Teaching English language using popular songs appears to be a very effective method as songs provide students with plethora of pronunciation patterns they can master in an effective and at the same time enjoyable way. Moreover, music influences students' feelings thus developing their emotional intelligence, ensure relaxed atmosphere in the classroom, thus motivating them to learn various aspects of English language. Another indisputable argument for using songs and music in the process of EFL/ESL teaching is that these two notions have a lot in common. Both language and music have acoustic parameters like pitch, duration, stress and intonation. Having analyzed the research works of domestic and foreign scholars and practitioners, it was concluded that popular songs can be used to practice all language skills - grammar, vocabulary, reading, listening, writing and most importantly, pronunciation skills. It is clear that inadequate phonetic interpretation of the vocal text can cause deviation from the original (authentic) content and result in total misunderstanding or spoilt
\end{abstract}


aesthetic perception of a song. In the process of mastering pronunciation with vocalists, it is necessary to take into account the peculiarities of vocal speech too. The article focuses on the methodological value of popular songs in the development of phonetic abilities in students majoring in music arts. The article also outlines the difficulties students face in the process of honing phonological skills such as certain consonant sounds and diphthongs as well as connected speech and provides the methodological approach to using songs in the classroom. It is strongly advised that language instructors carefully select the songs, taking into account many factors such as the students' level of English, age, and interests, as well as the complexity of the songs and their rhythm. It is recommended to follow a certain sequence of activities when working on the song material in order to facilitate the process of improving pronunciation of English sounds

Key words: pronunciation, popular songs, lyrics, song material, foreign language, phonetic skills, teaching techniques, methods of teaching

Introduction. There is no denial that songs is an invaluable source in teaching English language as they can be used for a variety of purposes: developing pronunciation skills, boosting vocabulary, practicing speech skills, teaching the cultural peculiarities of the country of the target language, as well as to developing grammatical skills. Indeed, songs are a means of more effective learning of vocabulary items, as they include new words, idioms, collocations and expressions and they appear in a new contextual environment, which helps to activate them. Lyrics often contain proper names, geographical names, the realities of the country of the target language, poetic words, which contributes to the development of students' sense of the language, knowledge of its stylistic features. Moreover, songs and music are effective methods of influencing students' feelings and emotions thus developing their inspiration and motivation. Another indisputable argument for using songs and music in the process of EFL/ESL teaching is that these two notions 
have a lot in common. Both language and music have acoustic parameters like pitch, duration, stress and intonation.

Problem statement. Teaching English using popular songs is especially relevant when it comes to teaching students majoring in vocals because they are closely connected with music and often practice singing English songs and doing it correctly is their main priority.

Analysis of recent research and publications. The effectiveness of using songs in the process of teaching a foreign language has been described in the research works of many domestic and foreign authors, among them: Kellaris J., Cox A., Cox D., Kumaravadivelu B., Kuśnierek, A. Liddicoat A., Scarino A., Millington Neil T., Vasquez A., Hansen A., Smith P., Roseboro, A.J.S., Krashen S., Aitov V., Vygotsky L. and others. Songs and music as the valuable material for teaching foreign languages are studies from different angles in scientific literature. Stephen Krashen, for instance, is considering songs through the prism of the emotional constituent. According to Stephen Krashen, the main obstacle to learning a foreign language is an "emotional filter" - emotionally induced mental block. Emotional education filter may be due to factors such as motivation, self-confidence and anxiety [3, p. 24]. So, students with high motivation, high self-confidence and low worries are more successful in mastering a foreign language. Incorporating popular songs in the esl/efl practice significantly reduce such negative emotions as anxiety and embarrassment thus contributing to more relaxed and effective foreign language acquisition. Creation of emotionally comfortable classroom atmosphere is the main precondition for successful work. Liddicoat A.J. and Angela S. in their research emphasize the significant improvement of memory due using songs in the process of learning a foreign language. Due to its ability to involve the emotional sphere of students, song material can be used as an important medium creating a favorable psychological climate in the lesson, which opens up physiological and psychological reserves in a learner and contributes to the development of their emotional intelligence [6, p. 56]. The utter goal of foreign language acquisition is automatic understanding and use 
of language patterns and this process may be facilitated when listening to music. Kuśnierek A. claimed in his research that the automated mechanism is quick, unstoppable, and occurs without the need for human intervention [5, p.43]. Songs can be helpful in the automation of the language learning process.

Other scholars like James Kellaris and Anthony Cox are doing research into the effects of music on the brain and thinking. They have proved that music is able to change the way the human brain works and make it more susceptible to learning. Music unites the activities of the right and left hemispheres of the brain, allowing them to collaborate and making learning more efficient [2, p.114]. Motivational aspects of using songs in the classroom are investigated by such researchers as Roseboro, Vasquez, Millington and others. Song lyrics that are also poetry may be highly motivating and acceptable for presenting in class. Students will perceive them as being a part of the learning process since they help create the lessons. Teachers may choose to gather and read the lyrics first, and then utilize them for a lesson later in the course, depending on the pupils to teach. If teachers have time, as Anna J. Small Roseboro advises, they can have students bring in ten-to-fifteen-second musical samples of the choruses for their chosen song lyrics and play a couple of these as instances of lyrical repetition [8, p. 18].

The purpose of this research is to substantiate the effectiveness of teaching students majoring in music arts English pronunciation with the help of popular songs, outline the difficulties students face in the process of mastering pronunciation and provide the methodological approach to using songs in the classroom.

Presentation of the main research material. It should be noted, that some questions of the use of song material in the educational process remain unexplored until now. Currently, there is no single methodological manual for teachers of a foreign language, which would contain specially selected methodological recommendations, techniques and forms, appropriate exercises, as well as a sequence of work with songs in order to achieve the formulated and set goals of teaching a foreign language at the initial stage. Meanwhile, as observations and practical studies show, 
foreign songs are very attractive for students, especially those students whose major is music arts. Unfortunately, the phonological aspect of the vocal realization of the text is has not yet found full and wide coverage in linguistics and methodical literature on vocal performance. However, in our opinion, a phonological approach seems the productive to train a vocal articulation in a non-native (English) language as this approach provides the vocalists with comprehensive knowledge of English sounds, their nature and extensive practice of mastering them. It goes without saying that further research into the phonetics of vocal language is required in order to develop the relevant guidelines and scientifically grounded model for the formation of special phonetic competences in vocalists. This requires the knowledge of specialists in the field of speech and singing voice physiology, psychoacoustics and psycholinguistics.

Teaching pronunciation is one of the most important steps in terms of practical significance in terms of developing speech skills. The stable, competent pronunciation of students is a prerequisite for the rapid and thorough assimilation of language material; it contributes to the successful development of skills in speaking, listening, reading and writing [4, p.48].

Phonetics and phonology are branches of linguistics that study the sound structure of a language, which serves as a material form of language and is in a very complex relationship with the biological and social nature of a human being. Obviously, it is very important to pay special attention to the concept of "phoneme" as one of the fundamental terms of modern theoretical linguistics as this knowledge is considered the basis of high-quality pronunciation. Correct intonation, understanding of the significance of pauses, knowledge of the features and types of stress of words in a sentence, as well as correct articulation of the speech apparatus - all these inseparable elements of good pronunciation are of vital importance to the students practicing vocal.

Correct phonetic skills will allow students to correctly pronounce all the sounds of the foreign language, to master the differential signs of sounds (publicity and consistency, hardness and softness, deafness and sonority). Phonetic skills will help students 
learn rhythm (alternation of stressed and unstressed syllables), logical stress of significant words, stress of auxiliary words (auxiliary verbs in negative and interrogative forms).

When mastering a foreign language pronunciation, the primary goal is to adapt the psychophysiological mechanisms of perception and production of speech according to the phonetic nature of the target language by correcting the existing and developing additional pronunciation skills. The creation of the auditorypronunciation base is possible only thanks to the potential abilities of the human ear and the mobility of the organs of the articulatory apparatus. In this case, timely correction of the problems that have arisen is very important [7, p.135]. The main requirement for pronunciation, from a scientific point of view, is the degree of correctness of the phonetic design of speech, the degree of automation of pronunciation skills. Mastering the correct pronunciation is possible only with the correct assimilation of the phonetic base of a foreign language at the level of syllable, word stress and intonation.

It is known that the esl/efl methodology distinguishes between imitative and analytic-imitative methods of practicing the new phonetic material. The imitative method focuses on the auditory perception of speech and its imitation, rather than the conscious assimilation of the peculiarities of articulation. The analyticalimitative approach, on the other hand, combines various methods of creating new sound images, models: description and articulation, imitation, understanding. Nowadays, the analytical-imitative method is mostly used in explaining and training pronunciation.

In addition to common language skills, vocational training of musicians-vocalists involves the formation of singing skills in English. This aspect is the most challenging in foreign language training. Obviously, vocal teachers are more focused on the tasks of voice production, sound quality learning, the correct vocal position of the articulatory apparatus, singing diction and so on. Unfortunately, little attention is paid to the question of observance of English pronunciation norms. However, the problem of correct pronunciation is of pivotal importance and requires special approach 
to solving it. It is clear that inadequate phonetic interpretation of the vocal text can cause deviation from the original (authentic) content and result in total misunderstanding or spoilt aesthetic perception of a song. In the process of working with pronunciation, it is necessary to take into account the peculiarities of vocal speech. Vocal or singing speech represents a different, special form of sounds of the particular language. In terms of musical beat, the vocal articulation of the word is rhythmically and pitch-organized. Language as a system of vowels and consonants, functioning in speech, receives its modification in a musical form, which has its own pronunciation norms. It is extremely important to realize that the transition to another language means a transition to a different system (phonemic and rhythmic) [1, p.12]. Articulating position of sounds, consonants and especially vowel phonemes, does not coincide with the usual movements of the articulatory apparatus in the native language. The process of working on English pronunciation using popular songs can be divided into two main aspects: vocal (correct voice formation and breathing, intonation, voice and phrasing) and pronunciation (clarity of diction). For the time being, the most widespread method of teaching the vocalists pronunciation is socalled imitation method, the essence of which is imitating different sound without deep understanding of their nature. However, some sounds in English language do not have any equivalent in Ukrainian language that is why vocalists must understand the principle of articulating these sounds, not just imitate them. For instance, Ukrainian speakers find it difficult to distinguish between the vowel sounds /i:/ and /i /, noticing no difference between "leave" and "live" or "sheep" and "ship". As a result, these words are commonly mispronounced, which causes deviation from the content. Some English consonants are really challenging for Ukrainian speakers, for instance the nasal "-ing" sound /In/, the "K" in "-ink"/Ink/, "th" sound $/ \theta /$, which often comes out as more of an "s", leading nonnative speakers to say "sink" instead of "think". Sounds /v/ and /w/, some interdental sounds, nasal sonant and diphthongs also cause pronunciation problems with Ukrainian vocalists and require special training exercises to master them. 
The understanding of such difficulties can help to clearly organize the work with a song. At the initial stage of working on phonetics, it is necessary to pay attention to the melody of the songs, i.e. aspirated sounds, alternation of stressed and unstressed syllables and words, vowels and consonants, etc. Certain peculiarities must be considered when choosing songs to teach specific consonant, vowel, or diphthong sounds. Since Ukrainian and English languages differ in their sound ranges, students must learn to 'physically' make sounds that they do not practice in their native language. Incorrectly spoken sounds can alter the meaning of the word, consequently, influencing the emotional and contextual connotation of the whole song. A teacher can direct students' attention to specific sounds and build activities around them. Working with rhymes in a song is an effective method to teach pronunciation. One of the activities can be using gaps to substitute some of the rhymes in the song. Students listen and fill in the blanks, guided by the song. It is also possible to let students categorize the words based on their sounds. It is important to make students listen to songs several times, thereby exposing them to the sounds.

The most challenging aspect of pronunciation is connected speech, which is the natural way for native English speakers to communicate. Rather than pronouncing each word standing alone, they connect words together and highlight particular syllables. Contractions are an extreme illustration of how the English speakers link speech. Songs can help tackle this pronunciation dilemma because this form of poetry is packed with contractions that students are eager to imitate. Songs with word combinations like "I am", "I can't see", and others will be quite useful. As Vasquez, Angela, and Philip propose, such contractions will help students to practice speaking short sentences independently [9, p.51].

Another technique, which definitely bears fruits in mastering pronunciation, is memorizing the text. Moreover, this technique is especially helpful for singers because they have to learn the lyrics by heart. There are different ways of memorization, which can be successfully practiced in both in the classroom and individually. For instance, the exercise called "Chain" when each student in turn 
pronounces one line of the first (second, third, etc.) verse and so on to the end, including choruses and bridges, proves to be very effective in memorizing lyrics. It is possible to offer students to complete the phrase. One student pronounces the beginning of a phrase and other students finish it in turn. A teacher's job is to monitor the process and identify errors, correct them after the task is completed. A well-known exercise "Snowball" (each subsequent student repeats the phrase of the previous one and adds his own) must be frequently practiced too in order to improve both pronunciation skills and memory. There is a plethora of similar exercises, however they should be selected in accordance with the topic of the lesson and the degree of correlation with the song itself. Obviously, the most important exercise, which ensures production of the language rather than its perception, is singing. Singing can be practiced either a cappella, without instrumental accompaniment, to the instrumental music or lip lynching. All these forms are suitable for effective practicing pronunciation. It is possible to offer various training techniques like substitution drilling (repeating a structure that substitutes few items with different vocabulary but with same form of the sentence), associating sounds with ideas (associating different sounds with some creative ideas: the vowel sound [i:] can be referred to as a 'smiling' sound.), using a phonemic chart, which helps the learners to enhance their pronunciation independently, outside the classroom, practicing tongue twisters, etc.

As far as the methods of teaching using popular songs go, it is necessary to develop a system of exercises, which will be able achieve the educational goals. Depending on these goals (e.g. training grammar structures, facilitating communicative skills, boosting vocabulary, mastering pronunciation, etc.), a teacher can design various exercises. Among others, the following types of exercises are widely used in EFL/ESL teaching:

- $\quad$ finding and correcting grammar mistakes;

- $\quad$ transforming one verb tense into another;

- dramatizing a song;

- $\quad$ conveying the content of the song in your own words; 
filling the gaps with the missing words (given or not given); recovering a song (guessing the rhyme);

putting the lines in the right order;

discussing the issues raised in a song, etc.

Undoubtedly, the types and number of exercises can vary depending on the learning goals and song material itself, however in order to gain the most benefit out of using songs in the classroom, it is recommended that a teacher follow the certain sequence of working with a song. In our opinion, the following sequence is

- musical presentation of the song (students analyze and discuss musical peculiarities of the song - melody, rhythm, character, mood, tonality, etc.);

- (making sure students understand the meaning of the lyrics);

- phonetic development of the song lyrics;

- re-listening to a song - work based on text (visualization of text using video or pictures);

- reading the text of the song with further development of sounds and intonation, work based on the lyrics of the song (completing related tasks);

learning in the process of joint performance of a song using a phonogram, staging a song, selection of additional visual materials. Thus, introducing this lesson structure and the recommendations helps increase the efficiency of using songs significantly. However, if a language instructor wants the song to fulfill its educational functions to the fullest, it is necessary to adhere to a certain algorithm for its use. First of all, the song should be carefully selected so that it meets the following requirements:

1) a song must be authentic;

2) a song must correspond to the students' level of English;

3) a song must be useful in terms of practicing the particular intonation and pronunciation patterns;

4) a song must reflect the interest of modern students due to its authentic cultural content.

If the choice of a song does not follow these principles, potentially it cannot be very useful. 
Conclusions. The usage of popular music in the process of foreign language acquisition has a number of indisputable advantages, which make this resource really valuable for all participants of the learning process. Firstly, music carries a spiritual origin and forms a positive, relaxed environment in the classroom. It also forms the aesthetic attitude of students to a foreign language culture and its features. Secondly, the use of the song allows to strengthen the motivational factor in teaching a foreign language, to increase the interest of students in the study of any material, which can contribute to the successful solution of psychological issues related to foreign language learning. Furthermore, songs assist students in improving their knowledge and production of essential pronunciation patterns since in music, as well as in speech, there are concepts such as intonation, pause, stress, tempo, pitch, aspiration, etc. Mastering pronunciation skills is of pivotal importance to those whose future profession is closely related to singing songs in English. However, it is strongly advised that language instructors carefully select the songs, taking into account many factors such as the students' level of English, age, and interests, as well as the complexity of the songs and their rhythm. The recommended stages of working on the song material are called to facilitate the process of language acquisition as well as contribute to the mastering of English pronunciation.

\section{References:}

1. Carr, P. (2016). A Glossary of Phonology. Edinburgh: Edinburgh University Press Ltd. [in English]

2. Kellaris, J. \& Cox, A. \& Cox, D. (1993). "The Effect of Background Music on Ad Processing: A Contingency Explanation", 114 Journal of Marketing, October, 1993, 57 (October, 1993) [in English]

3. Krashen, S. (1982). Principles and Practice in Second Language Acquisition. California: Pergamon Press Inc. [in English]. 4. Kumaravadivelu, B. (2013). Beyond Methods: Macrostrategies for Language Teaching. Washington: Yale University [in English] 
5. Kuśnierek, A. (2016) The role of music and songs in teaching English vocabulary to students. World Scientific News, 43(1) [in English]

6. Liddicoat, A.J. \& Scarino, A. (2013). Intercultural Language Teaching and Learning. USA: Wiley and Blackwell [in English]

7. Millington, Neil T. (2011). "Using Songs Effectively to Teach English to Young Learners". Journal of Language Education in Asia, 2011, 2(1), 134-141. Japan: Ritsumeikan Asia Pacific University [in English]

8. Roseboro, A.J.S. (2010). Teaching Middle School Language Arts: Incorporating Twenty-first-Century Literacies. UK: Rowman \& Littlefield Education [in English]

9. Vasquez, A. \& Hansen, A. \& Smith P. (2010). Teaching Language Arts to English Language Learners. New York: Routledge [in English]

\author{
Наталія Вячеславівна ЗЕМЛЯНСЬКА, \\ кандидат наук $з$ державного управління, \\ Київська муніципальна академія \\ естрадного та циркового мистецтв, \\ Київ, Україна, \\ e-mail: n.zemlyanska@kmaecm.edu.ua, \\ ORCID: 0000-0002-2192-8380
}

\title{
ВИКОРИСТАННЯ ПОПУЛЯРНИХ ПІСЕНЬ ДЛЯ ВИВЧЕННЯ АНГЛЙСЬКОЇ МОВИ СТУДЕНТАМИ СПЕЦАЛЬНОСТІ «МУЗИЧНЕ МИСТЕЦТВО». ФОНОЛОГІЧНИЙ АСПЕКТ
}

Анотація. У процесі вивчення іноземної мови студенти можуть зіткнутися 3 різними труднощами, які можуть перешкодити їм досягти бажаної мети. Вимова англійської мови традиційно вважається однією $з$ найскладніших проблем, для вирішення якої потрібні особливий підхід та методи навчання. Викладання англійської мови за допомогою популярних пісень видається достатньо ефективним методом, оскільки пісні 
надають студентам безліч фонологічних шаблонів, які вони можуть опанувати ефективним і водночас приємним способом. Крім того, музика впливає на почуття студентів, розвиваючи їхній емоційний інтелект, забезпечуючи невимушену атмосферу в аудиторії, мотивуючи їх таким чином вивчати різні аспекти англійської мови. Ще один незаперечний аргумент щодо використання пісень та музики у процесі вивчення іноземної мови, - це те, що ці два поняття мають багато спільного. Як і мова, музика має такі акустичні параметри, як висота звуку, тривалість, наголос та інтонація. У статті зосереджено увагу на методологічній цінності популярних пісень у розвитку фонетичних здібностей у студентів спеціальності «Музичне мистецтво». За результатами аналізу науково-дослідницьких робіти вітчизняних та зарубіжних учених і практиків автором було зроблено висновок, що популярні пісні можна використовувати для відпрацювання всіх мовних навичок граматики, словникового запасу, читання, аудіювання, письма та, найголовніше, навиків вимови. У статті також описуються труднощі, з якими стикаються студенти у процесі оволодіння вимовою, надається методичний підхід до використання пісень на заняттях із іноземної мови.

Ключові слова: вимова, популярні пісні, тексти пісень, пісенний матеріал, іноземна мова, фонетичні навички, методи навчання

\section{Список використаної літератури:}

1. Carr, P. (2016). A Glossary of Phonology. Edinburgh: Edinburgh University Press Ltd. [in English]

2. Kellaris, J. \& Cox, A. \& Cox, D. (1993). "The Effect of Background Music on Ad Processing: A Contingency Explanation", 114 Journal of Marketing, October, 1993, 57 (October, 1993) [in English]

3. Krashen, S. (1982). Principles and Practice in Second Language Acquisition. California: Pergamon Press Inc. [in English] 
4. Kumaravadivelu, B. (2013). Beyond Methods: Macrostrategies for Language Teaching. Washington: Yale University [in English]

5. Kuśnierek, A. (2016) The role of music and songs in teaching English vocabulary to students. World Scientific News, 43(1) [in English]

6. Liddicoat, A.J. \& Scarino, A. (2013). Intercultural Language Teaching and Learning. USA: Wiley and Blackwell [in English]

7. Millington, Neil T. (2011). "Using Songs Effectively to Teach English to Young Learners". Journal of Language Education in Asia, 2011, 2(1), 134-141. Japan: Ritsumeikan Asia Pacific University [in English]

8. Roseboro, A.J.S. (2010). Teaching Middle School Language Arts: Incorporating Twenty-first-Century Literacies. UK: Rowman \& Littlefield Education [in English]

9. Vasquez, A. \& Hansen, A. \& Smith P. (2010). Teaching Language Arts to English Language Learners. New York: Routledge [in English]

\section{Наталия Вячеславовна ЗЕМЛЯНСКАЯ,}

кандидат наук государственного управления,

Киевская муниципальная академия

эстрадного и циркового искусств,

Киев, Украина,

e-mail: n.zemlyanska@kmaecm.edu.ua,

ORCID: 0000-0002-2192-8380

\section{ИСПОЛЬЗОВАНИЕ ПОПУЛЯРНЫХ ПЕСЕН В ОБУЧЕНИИ АНГЛИЙСКОМУ ЯЗЫКУ СТУДЕНТОВ СПЕЦИАЛЬНОСТИ «МУЗЫКАЛЬНОЕ ИСКУССТВО». ФОНОЛОГИЧЕСКИЙ АСПЕКТ}

Аннотация. В процессе изучения иностранного языка студенты обычно сталкиваются с различными трудностями, которые могут помешать им достичь желаемой цели. 
Английское произношение традиционно считается одной из самых сложных проблем, для решения которой требуются особый подход и методы обучения. Обучение английскому языку с использованием популярных песен является чрезвычайно эффективным методом, поскольку песенный материал обеспечивает студентов множеством моделей произношения, которые они могут освоить эффективным и, в то же время, приятным способом. Кроме того, музыка влияет на чувства студентов, тем самым развивая их эмоциональный интеллект, обеспечивает непринужденную атмосферу в аудитории, тем самым мотивируя их изучать различные аспекты английского языка. Еще один неоспоримый аргумент в пользу использования песен и музыки в процессе обучения иностранному языку заключается в том, что эти два понятия имеют много общего. И язык, и музыка имеют акустические параметры, такие как высота звука, продолжительность, ударение и интонация. В статье акцентируется внимание на методическом значении популярных песен в развитии фонетических способностей студентов музыкального направления. По результатам анализа исследований отечественных и зарубежных ученых и практиков автором был сделан вывод, что популярные песни можно использовать для отработки всех языковых навыков - грамматики, словарного запаса, чтения, аудирования, письма и, самое главное, навыков произношения. В статье также описаны трудности, с которыми студенты сталкиваются в процессе овладения произношением, предложен методический подход к использованию песен на занятиях по иностранному языку.

Ключевые слова: произношение, популярные песни, тексты песен, песенный материал, иностранный язык, фонетические навыки, методика обучения 